\title{
Aggregates morphometry in a Latosol (Oxisol) under different soil management systems
}

\section{Morfometria de agregados de um Latossolo sob diferentes sistemas de manejos do solo}

\author{
Carla Eloize Carducci ${ }^{1 *}$; Antônio Carlos Tadeu Vitorino ${ }^{2}$; \\ Milson Evaldo Serafim ${ }^{3}$; Erika Andressa da Silva ${ }^{4}$
}

\begin{abstract}
Changes in soil physical properties are inherent in land use, mainly in superficial layers. Structural alterations can directly influence distribution, stability and especially morphometry of soil aggregates, which hence will affect pore system and the dynamic process of water and air in soil. Among the methods used to measure these changes, morphometry is a complementary tool to the classic methods. The aim of this study was to evaluate structural quality of a Latosol (Oxisol), under different management systems, using morphometric techniques. Treatments consisted of soil under no-tillage (NT); pasture (P), in which both had been cultivated for ten years, and an area under native vegetation (NV - Savannah like vegetation). Aggregates were sampled at depths of $0-0.10$ and $0.10-0.20 \mathrm{~m}$, retained on sieves with 9.52 $-4.76 \mathrm{~mm}, 4.76-1.0 \mathrm{~mm}, 1.0-0.5 \mathrm{~mm}$ diameter ranges. Aggregate morphometry was assessed by $2 \mathrm{D}$ images from scanner via QUANTPORO software. The analyzed variables were: area, perimeter, aspect, roughness, Ferret diameter and compactness. Moreover, disturbed samples were collected at the same depths to determine particle size, aggregate stability in water, water-dispersible clay, clay flocculation index and organic matter content. It was observed that different soil management systems have modified soil aggregate morphology as well as physical attributes; and management effects' magnitude increased from NT to P.
\end{abstract}

Key words: Image analyses, soil structural quality, conservationist management systems

\section{Resumo}

As alterações dos atributos físicos do solo, principalmente nas camadas superficiais, são inerentes ao uso do solo. Mudanças estruturais podem influenciar diretamente a distribuição, estabilidade e especialmente a morfometria dos agregados, o que afeta o sistema poroso e todo o processo dinâmico da água e ar no solo. Entre as metodologias que permitem mensurar estas alterações a morfometria apresenta-se como uma ferramenta complementar aos métodos tradicionais. Objetivou-se com esse trabalho avaliar a qualidade estrutural de um Latossolo Vermelho Distroférrico sob diferentes manejos do solo, empregando técnicas morfométricas. Os tratamentos deste estudo foram: o sistema plantio direto (PD), pastagem (P) ambos com dez anos de cultivo e área sob vegetação nativa (VN - Cerrado).

1 Prof. Dr., Universidade Federal de Santa Catarina, UFSC, Campus de Curitibanos, Curitibanos, SC, Brasil. E-mail: ec.carducci@ ufsc.br

2 Prof. Dr. Adjunto IV, Faculdade de Ciências Agrárias, Universidade Federal da Grande Dourados, UFGD, Dourados, MS, Brasil. E-mail: vitorino@ufgd.edu.br

3 Prof. Dr. D3, Instituto Federal do Mato Grosso, IFMT, Campus Cáceres, Cáceres, MT, Brasil. E-mail: milson.serafim@cas.ifmt. edu.br

4 Eng $^{\mathrm{a}}$ Agr ${ }^{\mathrm{a}}$, Discente do Curso de Doutorado, Dept ${ }^{\mathrm{o}}$ de Ciência do Solo, Universidade Federal de Lavras, DCS/UFLA, Lavras, MG, Brasil. E-mail: andressaerikasilva@gmail.com

* Author for correspondence 
Foram amostrados agregados nas camadas de 0-0,10 e 0,10-0,20 m retidos no intervalo de 9,52-4,76 $\mathrm{mm}, 4,76-1,0 \mathrm{~mm}, 1,0-0,5 \mathrm{~mm}$ de diâmetro, obtidos por meio de um jogo de peneiras padrão. As análises dos agregados foram realizadas por meio de imagens 2D obtidas via scanner e analisadas com o programa QUANTPORO. As variáveis morfométricas avaliadas foram: Área, Perímetro, Aspecto, Rugosidade, Diâmetro de Ferret e Compacidade. Amostras com estrutura deformada foram coletadas nas mesmas profundidades para as seguintes determinações: granulometria, estabilidade de agregados em água, argila dispersa em água, grau de floculação e o conteúdo da matéria orgânica. Os diferentes sistemas de manejo do solo modificaram a morfometria dos agregados do solo, bem como seus atributos físicos, sendo que a magnitude dos efeitos causados pelo manejo aumenta no sentido do PD para a P.

Palavras-chave: Análise de imagem, qualidade estrutural do solo, sistemas conservacionistas

\section{Introduction}

Current agriculture's greatest challenge is to seek sustainability or new balance conditions in production system, which concerns, among others, a conservation management. Soil management practices influence on soil structuring, i.e., they affect aggregate size, distribution and stability, in addition to soil particle shape and adhesion (OLZEVISKI et al., 2004). Therefore, knowing soil structural quality and its variation throughout the time is crucial to predict such effects (VIANA et al., 2004).

This way, several researches have been carried out to draw structural quality indexes by monitoring the effects of management practices on soil physical, chemical, water and biological attributes (BERGAMIN et al., 2010; LIMA et al., 2012; OLIVEIRA et al., 2004; SEVERIANO et al., 2009); besides organic matter dynamic along its profile (COSTA JUNIOR et al., 2012; SILVA et al., 2013; TIRLONI et al., 2012).

For the quantitative understanding of soil structure, a good index to evaluate the soil quality should be grounded in aggregates image analysis. Such technique, known as morphometry, enables aggregate characterization according to geometric forms (main axes relationship), it can be performed by means of $2 \mathrm{D}$ image processing techniques, which have low cost and are easy to handle (CREMON et al., 2011; OLSZEVSKI et al., 2004; VIANA et al., 2004).

Furthermore, image analyses have high power prediction to detected changes on soil aggregate morphology, enabling a numerical expression of the structure form and size; not only for descriptive purposes, but also to perform quantitative studies of several factors, even particle or fragment final shape (CREMON et al., 2009).

Additionally, it noteworthy to mention that proper morphometric conditions will be find in soils under original vegetation; since it has no human action and increased organic matter level, contributing to structure stability (COSTA JUNIOR et al., 2012; SALTON et al., 2008; TIRLONI et al., 2012). Unfortunately, these conditions change when inserted into a productive process and which therefore changes soil structuring at different magnitude levels (OLIVEIRA et al., 2004; SEVERIANO et al., 2009).

Given the above, this study aimed to evaluate the structural quality of an Oxisol (Latosol) under different management systems by means of morphometric analyses.

\section{Material and Methods}

The study was performed in an experimental area located on MS-270 Road, $\mathrm{km} 8$, in the city of Dourados - MS, Brazil with the $22^{\circ} 12$ ' 39.17' S and $54^{\circ} 54^{\prime} 28.44^{\prime \prime} \mathrm{W}$ geographical coordinates, at an altitude of $430 \mathrm{~m}$. As seen in Table 1, the soil was classified as a clayey dystroferric Red Latosol (Oxisol), LVdf type, by the Embrapa (2013). The climate was defined according to Köepen's classification as Cwa (mesothermal humid subtropical, with hot summers and dry winters) (FIETZ; FISCH, 2008). 
The experimental area was composed of two management systems and another area under environmental protection. One area has been cultivated under no-tillage system (NT) for 10 years with crop rotations (soybean/ oat during the first five years and soybean/ winter corn within the last five ones). The other area has been grown with pasture (P) of Brachiaria decumbens for 10 years of intensive grazing at a stocking rate of one animal per hectare, for one year; this area has no record of fertilization and degradation signs. Lastly, one area under environmental preservation (NV: clean savannah - Cerrado, secondary tropical forest) used as control treatment (HEID et al., 2009).

Table 1. Particle size of an dystroferric Red Latosol (Oxisol) under different management systems and soil depths.

\begin{tabular}{|c|c|c|c|c|c|c|c|c|c|}
\hline \multirow{3}{*}{$\begin{array}{c}\text { Depth } \\
\text { (m) }\end{array}$} & \multicolumn{3}{|c|}{ No-tillage } & \multicolumn{3}{|c|}{ Pasture } & \multicolumn{3}{|c|}{ Native Vegetation } \\
\hline & Clay & Silt & Sand & Clay & Silt & Sand & Clay & Silt & Sand \\
\hline & & & & & $\ldots \mathrm{g} \mathrm{k}$ & & & & \\
\hline $0-0.05$ & 614 & 182 & 139 & 668 & 219 & 113 & 683 & 217 & 98 \\
\hline $0.05-0.10$ & 663 & 200 & 137 & 673 & 213 & 114 & 711 & 199 & 90 \\
\hline $0.10-0.20$ & 683 & 196 & 121 & 703 & 183 & 115 & 727 & 196 & 76 \\
\hline
\end{tabular}

Trenches of $0.40 \times 0.40 \times 0.30 \mathrm{~m}$ were dug at five random points for each treatment. Wherein, disturbed soil samples were collected at $0-0.05$, 0.05-0.10 and 0.10-0.20 $\mathrm{m}$ depths for physical characterization. Morphometric analysis was performed using soil block samples $(0.15 \mathrm{~m}$ x 0.10 $\mathrm{m} \times 0.10 \mathrm{~m}$ ) collected at $0-0.10$ and 0.10 to 0.20 $\mathrm{m}$ depths due to structural similarity observed by visual assessment of the soil profile for the upper depths.

After sampling, soil blocks were placed on a standard set of sieves with mesh size ranges of 9.52 to $4.76 \mathrm{~mm}, 4.76$ to $1.0 \mathrm{~mm}$ and 1.0 to $0.5 \mathrm{~mm}$. We gently wiggled the set back and forth ten times. Next, the aggregates retained on each sieve were packaged in a flat, rigid plastic container wrapped by two layers of cotton (cover and bottom) to minimize damages to the original structure during transportation. Then, these samples were air dried before being subjected to image analysis.

Aggregates started to be analyzed after attaining 2D images from a flatbed scanner (HP Scanjet 6000C), with an optical resolution of 1200 dpi. Hereupon, the images were processed by QUANTPORO software (VIANA et al., 2004).
One sample of each depth containing 60 aggregates of each size was spread out over the scanner; a wooden frame designed with staggered openings had separated aggregate sizes. We used a $300 \mathrm{dpi}$ resolution for aggregates of 4.76-1.0-mm and 9.52 to $4.76 \mathrm{~mm}$ classes and $600 \mathrm{dpi}$ for 1.0 to $0.5 \mathrm{~mm}$.

QUANTPORO has a capacity to process and analyze various images and also measure or assess morphometric characteristics of any object. It was performed digitalization, using a $R G B$ system (red, green, blue); next, a median filter that changes each pixel value by neighbor pixels median filtered the images. This filter main effect play an important role in reducing isolate pixels, which can cause image noise and result in errors, especially regarding perimeter measurement.

All images were converted into binary format $[0,1]$, in other words, in black and white colors by way of a thresholding process, with posterior image processing through calibration plugins (spatial resolution) and QUANTPORO software classification (Figure 1).

Aggregate analyzed variables were: area - AR (number of pixels within the polygon); perimeter - PER (aggregates length of the exterior limit as 
edges); aspect ASP (shows the result between 0 and 1 , and when higher, its adjustment); roughness ROU (varying with aggregate surface roughness from 0 to
1, being flatter as value increases); Ferret diameter - F (circle diameter of an object with same area).

Figure 1. Image diagram to processing steps performed by QUANTPORO software. Image containing 28 aggregates.

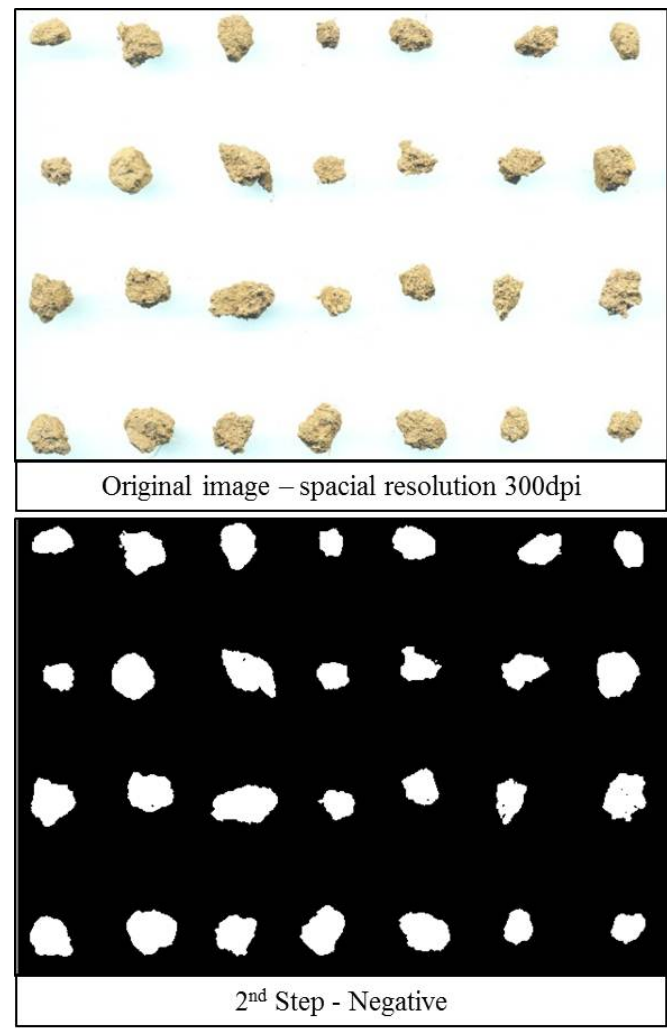

The Feret diameter is calculated through the following formula:

$$
\mathrm{F}=\sqrt{\left(\frac{4 A r}{\pi}\right)}
$$

wherein, Compactness (CMP) provides object circularity, and ranges with major axis length. This value varies from zero to one and, if it is equal to one, it may imply in complete aggregate roundness. It is calculated by the formula:

$\mathrm{CMP}=\sqrt{\left(\frac{4 A r}{\pi}\right) /}$ CME (CREMON et al., 2009; OLSZEVSKI et al., 2004).

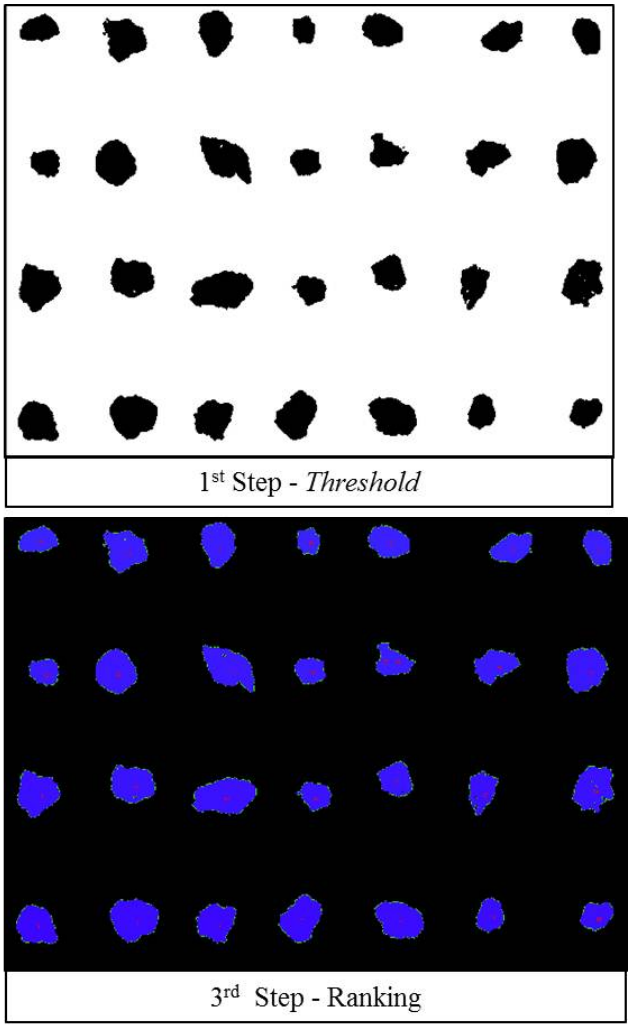

Disturbed samples were air dried and sifted through a $2-\mathrm{mm}$ mesh sieve to determine grain size using pipette method, water-dispersible clay (WDC), flocculation degree (DF) and organic matter content $(\mathrm{OM})$. Aggregate stability index was calculated using block samples, analyzing the geometric mean diameter (GMD) (EMBRAPA, 2011).

The experimental design was entirely randomized in a split-plot system of $3 \times 3$ (3 morphometry treatments per 3 meshes) and $3 \times 2$ (3 physical attributes and 2 depths) with five replications, in which plots stood for management systems and subplots for depths, and Tukey's test $(p<0.05)$ was performed for both factors by means of SISVAR software. 


\section{Results and Discussion}

Management systems presented significant differences among them for all physical attributes, including the morphometric variables ASP, CMP and ROUN. However, it was not observed for the other morphometric variables, even considering the good detail level of aggregate border analysis that eases the detection of slight variations (OLSZEVSKI et al., 2004).
The water-dispersible clay (WDC) was homogeneous along the soil profile, but varying with treatment showing the lowest WDC values for P, followed by NV compared with NT. It is worth reminding that the NT is already consolidated (after 10 years of planting). Although soil has not been inverted (BERGAMIN et al., 2010; BRAIDA et al., 2008) as in conventional planting, there is little soil inversion on planting line, besides liming and phosphate fertilization that might have caused clay dispersion (Table 2).

Table 2. Physical attributes of a dystroferric Red Latosol (Oxisol) under no-tillage (NT), pasture (P) and native vegetation $(\mathrm{VG})$ at different depths.

\begin{tabular}{cccc}
\hline Management & $\begin{array}{c}\mathrm{WDC}^{1} \\
\mathrm{~g} \mathrm{~kg}^{-1}\end{array}$ & $\begin{array}{c}\mathrm{DF}^{2} \\
\%\end{array}$ & $\begin{array}{c}\mathrm{GMD}^{3} \\
\mathrm{~mm}\end{array}$ \\
\hline $\mathrm{NT}$ & $219 \mathrm{a}$ & $66 \mathrm{~b}$ & $1.96 \mathrm{~b}$ \\
$\mathrm{P}$ & $173 \mathrm{~b}$ & $75 \mathrm{a}$ & $2.09 \mathrm{~b}$ \\
$\mathrm{NV}$ & $199 \mathrm{ab}$ & $72 \mathrm{a}$ & $2.52 \mathrm{a}$ \\
\hline \multirow{2}{*}{ Depth (m) } & $\mathrm{WDC}$ & $\mathrm{DF}$ & $\mathrm{GMD}$ \\
& $\mathrm{g} \mathrm{kg}^{-1}$ & $\%$ & $\mathrm{~mm}$ \\
\cline { 2 - 4 } $0-0.05$ & $200 \mathrm{a}$ & $69 \mathrm{~b}$ & $2.35 \mathrm{a}$ \\
$0.05-0.10$ & $208 \mathrm{a}$ & $69 \mathrm{~b}$ & $2.17 \mathrm{a}$ \\
$0.10-0.20$ & $184 \mathrm{a}$ & $74 \mathrm{a}$ & $2.05 \mathrm{a}$ \\
\hline
\end{tabular}

Means followed by the same lowercase letter in the column within treatment do not differ from each other by Tukey's test $(\mathrm{p}<$ 0.05). ${ }^{1}$ WDC: water-dispersible clay, ${ }^{2} \mathrm{DF}$ : flocculation degree, ${ }^{3} \mathrm{GMD}$ : geometric mean diameter.

Regarding $\mathrm{P}$ environment, it must be considered the action of the large and dense grass roots, which contribute to organic matter raise with depth. This fact directly implies in higher stability of soil aggregates and justifies higher flocculation degree (DF) and geometric mean diameter (GMD) values in P (COSTA JUNIOR et al., 2012; LIMA et al., 2012; SEVERIANO et al., 2009).

As shown in Table 2, there was a DF increment in the management systems that followed the order: $\mathrm{NV}=\mathrm{P}>\mathrm{NT}$. This result is related to grass and other vegetal coverings that benefit soil structure stabilization with their fascicular root system as aforementioned; they promote a soil particle entanglement (COSTA JUNIOR et al., 2012; SALTON et al., 2008).

As stated by Silva et al. (2000), the greatest DF at subsurface layers cannot be solely attributed to organic matter content, but also to soil genesis and mineralogy. Nevertheless, it is truly observed an influence of OM on the DF, which decreases with OM reduction (ROSA JUNIOR et al., 2006).

Table 2 also shows a GMD increment that followed the sequence: NV $>$ P $>$ NT, corroborating Silva et al. (2013, 2006) results. Lack of human interference and elevated OM content in NV might be possible explanations for GMD increase (Table 3). Once OM fractions act in soil structure stabilization (SALTON et al., 2008; SLEUTEL et al., 2012) by enhancing bond strength of mineral particles, which play an important role in aggregate stabilization and formation (BRAIDA et al., 2008; COSTA JUNIOR et al., 2012). Larger aggregates are usually indicative of good quality, once they own a well pore size distribution. 
It is noteworthy mention that the management systems and depths had variations in OM content, as shown in Table 3. The greatest OM content was found in NV at 0-0.05 and 0.05-0.10 m depths, followed by contents in P and NT. With respect to depths, OM decreases from P to NV and NT.

The pasture had greater OM content compared to NT at 0.010-0.20-m depth. Soares et al. (2005) reported that grass root system has an intense turnover rate, boosting the production of mucigels (exocellular polysaccharides by microorganisms), which favors soil aggregation mostly in long periods, as we observed in $\mathrm{P}$ area it's had more than ten years in this same management. It is important to highlight that OM increase is reflected on DF and GMD values as seen in $P$ area.

The aggregate surface indexes obtained by 2D image analysis, such as aspect (ASP, rounding degree), roundness (ROUN) that refer to surface roundness (CARVALHO et al., 2010) and compacity (CMP) that predicts how round is an aggregate (OLSZEVSKI et al., 2004). They were most predictive with regard morphological changes of aggregates promoted by management systems (Figure 2).

Table 3. Mean values of organic matter (OM) in a dystroferric Red Latosol (Oxisol) under no-tillage (NT), pasture (P) and native vegetation (NV) at different soil depths.

\begin{tabular}{|c|c|c|c|}
\hline \multirow{3}{*}{$\begin{array}{c}\text { Depth } \\
\text { (m) }\end{array}$} & NT & $\mathrm{P}$ & NV \\
\hline & \multicolumn{3}{|c|}{\begin{tabular}{lll}
\cline { 3 - 3 } & $\mathrm{OM}$ \\
\end{tabular}} \\
\hline & \multicolumn{3}{|c|}{ 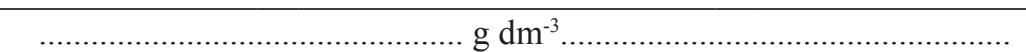 } \\
\hline $0-0.05$ & $3.75 \mathrm{Ba}$ & $3.82 \mathrm{Ba}$ & $5.82 \mathrm{Aa}$ \\
\hline $0.05-0.10$ & 3.06Bab & $3.72 \mathrm{ABa}$ & $4.24 \mathrm{Ab}$ \\
\hline $0.10-0.20$ & $2.66 \mathrm{Bb}$ & $3.84 \mathrm{Aa}$ & $3.53 \mathrm{ABb}$ \\
\hline
\end{tabular}

Means followed by the same lowercase letter in the column do not differ from each other by Tukey's test $(p<0.05)$.

Figure 2. Mean values of the variables ASP (aspect), ROU (roughness), CMP (compactness) of the treatments NT (no-tillage), P (pasture), NV (native vegetation). Means followed by the same letter among treatments do not differ from each other by Tukey's test at 5\%.

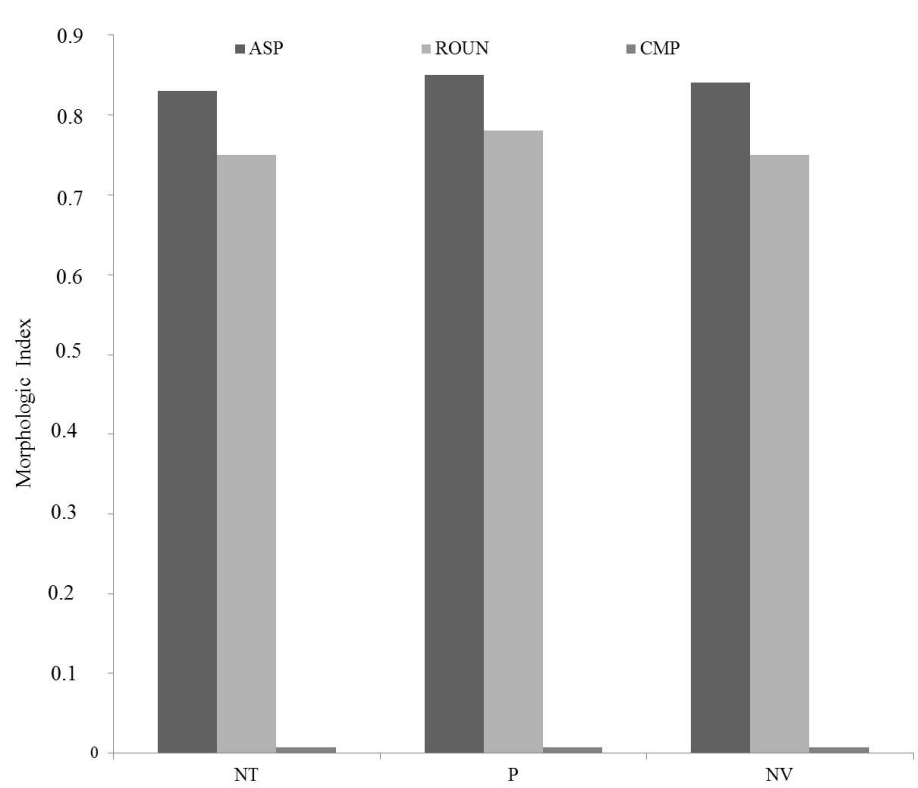


When compared to the other areas, $\mathrm{P}$ showed the greatest change in aggregate form (CMP). It is known that those indexes ranging from 0.70 0.85 refer to aggregates with square geometry predominantly, but tending to a round shape, or with rounded vertices (ASP), and smooth surface (ROUN) (CARVALHO et al., 2010).

In our study, these indexes ranged from 0.70 to 0.85 (Figure 2), similar to those detected by Cremon et al. (2011), who evaluated rice production systems (conventional, dry, rotational). These authors observed more rounded aggregate in conventional system $(>0.80)$ and more edged in rotational one $(<0.80)$. However such values were near the ones found by our study in NV, it's reflects the beneficial effects of minimum soil turning and OM increase provided by NT as well as the grass effect on OM replacement in $\mathrm{P}$.

In NT, morphometric variables pointed out for aggregates with striated surfaces and undefined forms, which enables a random structure organization (mismatched), increasing porosity and, as a result, an enhanced water and air flow (CARVALHO et al., 2010; CREMON et al., 2011).
Although good physical condition had been found in P soil (Table 2), it was not reflected into the aggregate morphology, which had various forms (ASP: \pm 0.85, ROUN: \pm 0.79, CMP: \pm 0.03 ) tending to become round (Figure 2). This trend may be due to animal and forage management (IMHOFF et al., 2000), as by root system action in aggregation levels (SALTON et al., 2008). In other words, this area will present larger degradation state than the others, if it continues being handled under the same intensive management system.

Upon examining aggregate size separately, according to the pre-established range of this study (9.52-4.76 mm; 4.76-1.0 mm; 1.0-0.5 mm), it was possible to detect morphometric differences among systems by aggregate dimensions. Aggregates retained on the 9.52-4.76-mm sieve (Table 4) in $\mathrm{P}$ had the greatest values of ASP, CMP and ROUN; probably because of grazing pressure (CONTE et al., 2007; IMHOFF et al., 2000) and lack of pasture management, once degradation signs were visible (exposed soil and forage nutrient deficiency). They promoted surface deformation of the bigger aggregates, despite values being still near those of NV.

Table 4. Aggregates Morphometry of a dystroferric Red Latosol (Oxisol) under no-tillage (NT), pasture (P) and native vegetation (NV) at different diameters.

\begin{tabular}{|c|c|c|c|c|c|c|}
\hline \multirow{2}{*}{ Management } & \multicolumn{6}{|c|}{$4.76-9.52 \mathrm{~mm}$} \\
\hline & $\mathrm{ASP}^{1}$ & $\mathrm{ROU}^{2}$ & $\mathrm{CMP}^{3}$ & $\mathrm{AR}^{4}$ & $\mathrm{PER}^{5}$ & $\mathrm{~F}^{6}$ \\
\hline NT & $0.82 \mathrm{a}$ & $0.70 \mathrm{a}$ & $0.0073 b$ & $0.40 \mathrm{a}$ & $2.64 \mathrm{a}$ & $0.72 \mathrm{a}$ \\
\hline $\mathrm{P}$ & $0.85 b$ & $0.71 \mathrm{a}$ & $0.0076 \mathrm{a}$ & $0.37 \mathrm{a}$ & $2.50 \mathrm{a}$ & $0.69 \mathrm{a}$ \\
\hline \multirow[t]{3}{*}{ NV } & $0.84 b$ & $0.66 \mathrm{~b}$ & $0.0074 b$ & $0.38 \mathrm{a}$ & $2.68 \mathrm{a}$ & $0.70 \mathrm{a}$ \\
\hline & \multicolumn{6}{|c|}{$1.00-4.76 \mathrm{~mm}$} \\
\hline & ASP & ROU & CMP & $\mathrm{AR}$ & PER & $\mathrm{F}$ \\
\hline NT & $0.83 \mathrm{a}$ & $0.75 \mathrm{a}$ & $0.0073 \mathrm{a}$ & $0.10 \mathrm{a}$ & $1.29 \mathrm{a}$ & $0.36 \mathrm{a}$ \\
\hline $\mathrm{P}$ & $0.85 \mathrm{a}$ & $0.78 b$ & $0.0074 \mathrm{a}$ & $0.10 \mathrm{a}$ & $1.24 \mathrm{a}$ & $0.35 \mathrm{a}$ \\
\hline \multirow{2}{*}{ NV } & $0.84 \mathrm{a}$ & $0.75 \mathrm{a}$ & $0.0073 \mathrm{a}$ & $0.11 \mathrm{a}$ & $1.34 \mathrm{a}$ & $0.38 \mathrm{a}$ \\
\hline & \multicolumn{6}{|c|}{$0.5-1.00 \mathrm{~mm}$} \\
\hline & ASP & ROU & CMP & $\mathrm{AR}$ & PER & $\mathrm{F}$ \\
\hline NT & $0.85 b$ & $0.84 \mathrm{a}$ & $0.0035 \mathrm{a}$ & $0.006 \mathrm{a}$ & $0.29 \mathrm{a}$ & $0.09 \mathrm{a}$ \\
\hline $\mathrm{P}$ & $0.87 \mathrm{a}$ & $0.84 \mathrm{a}$ & $0.0035 \mathrm{a}$ & $0.005 \mathrm{a}$ & $0.28 \mathrm{a}$ & $0.09 \mathrm{a}$ \\
\hline NV & $0.85 \mathrm{ab}$ & $0.84 \mathrm{a}$ & $0.0035 \mathrm{a}$ & $0.005 \mathrm{a}$ & $0.27 \mathrm{a}$ & $0.08 \mathrm{a}$ \\
\hline
\end{tabular}

Means followed by the same lowercase letter in the column within the diameter ranges do not differ from each other by Tukey's test at 5\%. ${ }^{1}$ ASP: aspect (rounding), ${ }^{2}$ ROU: roughness, ${ }^{3}$ CMP: compactness (roundness), ${ }^{4} \mathrm{AR}$ : surface area, ${ }^{5}$ PER: perimeter, ${ }^{6}$ F: Ferret diameter. 
For aggregates with 4.76-1.00-mm diameter, ROUN was the only attribute that showed a significant difference among management systems, with the largest value found for P to increase smoother aggregates. Contrarily, for 1.00-0.5-mm diameter aggregates, ASP was the one to present round shape of aggregates, which is expected because of the small size. They showed higher values for $\mathrm{P}$ and $\mathrm{NV}$, which may correspond to combined different effects that were not isolated. As an example, the gibbsite predominance within clay mineralogy that stimulates pseudo-silt formation (VITORINO et al.,
2003), and OM type and amount, since both areas showed good content of it (Table 3), and it can give greater elasticity to aggregates (BRAIDA et al., 2008).

Aggregate dimensions had different ranges, such as AR that varied from 0.005 to $0.400 \mathrm{~cm}^{2}$, PER from 0.27 to $2.68 \mathrm{~cm}^{2}$ and $F$ from 0.08 to 0.72 . Nonetheless, surface indexes (ASP, ROUN and CMP) ranged from $<0.03$ to $>0.80$ (non-dimensional) within the sieving ranges. It is expected that smaller aggregates are more round than spindled, as seen in this study (Table 4, Figure 3).

Figure 3. Aggregate distribution at different classes of the variables A) Aspect and B) Roughness referring to NT (notillage), $\mathrm{P}$ (pasture) and NV (native vegetation), related to the $0-0.20 \mathrm{~m}$ layer.

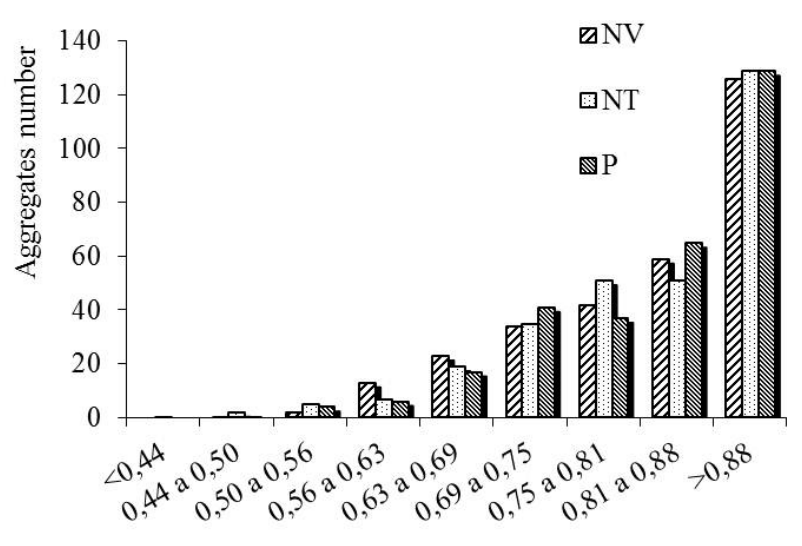

Aggregates Aspect

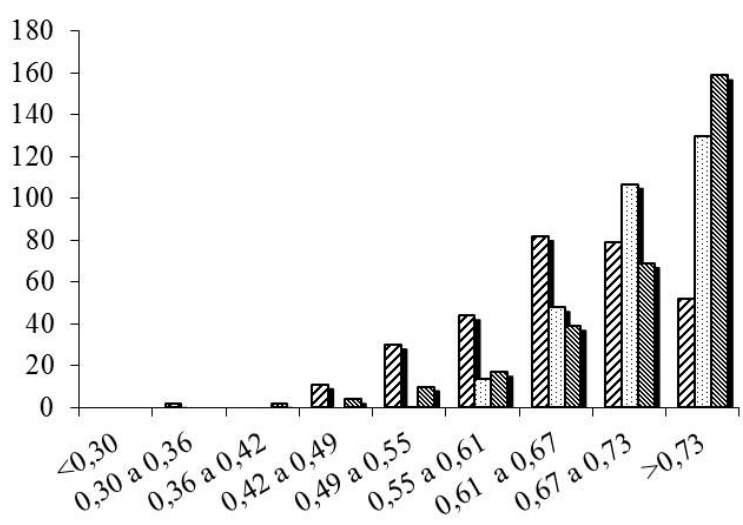

Aggregates Roundness
It was found that ASP and ROUN were the best predictors; and by means of their frequency distribution, they were divided into nine classes, in all management systems. Moreover, we checked a greater frequency of aggregates $>0.88$ for ASP and $>$ 0.73 for ROUN in all systems, it can be related both to grass root action for soil structuring (IMHOFF et al., 2000; SALTON et al., 2008; TIRLONI et al., 2012) and to the management adopted, as stated by Carvalho et al. (2010), these values represent aggregates of cubical shape with surface grooves and spindled edges; however, being on transition to a round and flat form (Figure 3 ).
The management systems changed aggregate morphology. It could be clearly explained by aggregate form, period and used management system. In addition, such changes have actually occurred, despite being a Latosol aggregates, which is a fairly weathered soil with granular structure that is considered very stable and homogeneous, especially in diagnostic horizon (FERREIRA et al., 1999; SEVERIANO et al., 2013).

It is worthy to mention that the adopted systems, with agricultural practices that favor soil structure preservation such as: vegetal covering, OM increase, little soil inversion (NT) and low animal 
stocking rate $(\mathrm{P})$, have contributed to soil physical quality improvement. Such fact can be assured by physical and morphological attributes evaluated; however, physical attributes did not reflect on aggregates morphology, and such alteration has just been detected by 2D image analysis of them, which becomes an effective tool for prediction of sustainability in agricultural systems.

\section{Conclusion}

The different management systems modified the morphology of soil aggregates, as well as their physical attributes. There were positive effects on attributes in pasture and negatives concerning their morphology. Soil aggregates under pasture had flatter and rounder surfaces compared to those under no-tillage and native vegetation.

\section{Acknowledgements}

To the Federal University of Grande Dourados for institutional support, and to the CNPq (National Council for Scientific and Technological Development) for financial support.

\section{References}

BERGAMIN, A. C.; VITORINO, A. C. T.; FRANCHINI, J. C.; SOUZA, C. M. A.; SOUZA, F. R. Compactação em um Latossolo Vermelho Distroférrico e suas relações com o crescimento radicular do milho. Revista Brasileira de Ciência do Solo, Viçosa, MG, v. 34, n. 3, p. 681-691, 2010.

BRAIDA, J. A.; REICHERT, J. M.; REINERT, D. J.; SEQUINATTO, L. Elasticidade do solo em função da umidade e do teor de carbono orgânico. Revista Brasileira de Ciência do Solo, Viçosa, MG, v. 32, n. 2, p. 477-485, 2008.

CARVAlHO, J. M.; CREMON, C.; MAPELI, N. C.; NUNES, M. C. M.; SILVA, W. M.; MAGALHÃES, W. A.; SANTOS, A. S. Análise micromorfométrica de agregados de um Latossolo Vermelho distroférrico sob diferentes sistemas de cultivo. Agrarian, Dourados, v. 3, n. 10 , p. $275-285,2010$.
CONTE, O.; LEVIEN, R.; TREIN, C. R.; CEPIK, C. T. C.; DEBIASI, H. Demanda de tração em haste sulcadora na integração lavoura pecuária com diferentes pressões de pastejo e sua relação com o estado de compactação do solo. Engenharia Agrícola, Jaboticabal, v. 27, n. 1, p. 220-228, 2007.

COSTA JÚNIOR, C.; PÍCCOLO, M. C.; SIQUEIRA NETO, M.; CAMARGO, P. B.; CERRI, C. C.; BERNOUX, M. Carbono em agregados do solo sob vegetação nativa, pastagem e sistemas agrícolas no Bioma Cerrado. Revista Brasileira de Ciência do Solo, Viçosa, MG, v. 36, n. 4, p. 1311-1321, 2012.

CREMON, C.; ROSA JÚNIOR, E. J.; SERAFIM, M. E.; ONO, F. B. Análise micromorfométrica de agregados de um Latossolo vermelho distroférrico em diferentes sistemas de manejo. Acta Scientiarum- Agronomy, Maringá, v. 31, n. 1, p. 139-146, 2009.

CREMON, C.; SACCO, D.; GRIGNANI, C.; ROSA JÚNIOR, E. J.; MAPELI, N. C. Micromorfometria de agregados do solo sob diferentes sistemas de cultivo de arroz. Pesquisa Agropecuária Tropical, Goiânia, v. 41, n. 3, p. 370-377, 2011.

EMPRESA BRASILEIRA DE PESQUISA AGROPECUÁRIA - EMBRAPA. Solos. Manual de métodos de análise de solo. 2. ed. revista. Rio de Janeiro: Embrapa Solos, 2011. 225 p.

. Solos. Sistema brasileiro de classificação de solos. Rio de Janeiro: Embrapa Solos, 2013. 353 p.

FERREIRA, M. M.; FERNANDES, B.; CURI, $N$. Influência da mineralogia da fração argila nas propriedades físicas de Latossolos da região sudeste do Brasil. Revista Brasileira de Ciência do Solo, Viçosa, MG, v. 23, n. 3, p. 515-524, 1999.

FIETZ, C. R.; FISCH, G. F. O clima da região de Dourados, MS. 2. ed. Dourados: CPAO, 2008. 34 p. (Documentos Embrapa CPAO, n. 92).

HEID, D. M.; VITORINO, A. C. T.; TIRLONI, C.; HOFFMAN, N. T. K. Frações orgânicas e estabilidade dos agregados de um Latossolo Vermelho distroférrico sob diferentes usos. Revista Ciências Agrárias, Belém, n. 51, p. 143-160, 2009.

IMHOFF, S.; SILVA, A. P.; TORMENA, C. A. Aplicação da curva de resistência no controle da qualidade física de um solo sob pastagem. Pesquisa Agropecuária Brasileria, Brasília, v. 35, n. 7, p. 1493-1500, 2000.

LIMA, V. M. P.; OLIVEIRA, G. C.; SERAFIM, M. E.; CURI, N.; EVANGELISTA, A. R. Intervalo hídrico ótimo como indicador de melhoria da qualidade estrutural de Latossolo degradado. Revista Brasileira de Ciência do Solo, Viçosa, MG, v. 36, n. 1, p. 71-78, 2012. 
OLIVEIRA, G. C.; DIAS JUNIOR, M. S.; RESCK, D. V. S.; CURI, N. Caracterização química e físico-hídrica de um Latossolo Vermelho após vinte anos de manejo e cultivo do solo. Revista Brasileira de Ciências do Solo, Viçosa, MG, v. 28, n. 2, p. 327-336, 2004.

OLSZEVSKI, N.; COSTA, L. M.; FERNANDES FILHO, E. I.; RUIZ, H. A.; ALVARENGA, R. C.; CRUZ, J. C. Morfologia de agregados do solo avaliada por meio de análise de imagens. Revista Brasileira de Ciências do Solo, Viçosa, MG, v. 28, n. 5, p. 901-909, 2004.

ROSA JUNIOR, E. J.; MARTINS, R. M. G.; ROSA, Y. B. J.; CREMON, C. Calcário e gesso como condicionantes físico e químico de um solo de Cerrado sob três sistemas de manejo. Pesquisa Agropecuária Tropical, Goiânia, v. 36, n. 1, p. 37-44, 2006.

SALTON, J. C.; MIELNICZUK, J.; BAYER, C.; BOENI, M.; CONCEIÇÃO, P. C.; FABRÍCIO, A. C.; MACEDO, M. C. M.; BROCH, D. L. Agregação e estabilidade de agregados do solo em sistemas agropecuários em Mato Grosso do Sul. Revista Brasileira de Ciência do Solo, Viçosa, MG, v. 32, n. 1, p. 11-21, 2008.

SEVERIANO, E. C.; OLIVEIRA, G. C.; CURI, N.; DIAS JUNIOR, M. S. Potencial de uso e qualidade estrutural de dois solos cultivados com cana-de-açúcar em Goianésia, GO. Revista Brasileira de Ciência do Solo, Viçosa, MG, v. 33, n. 1, p. 159-168, 2009.

SEVERIANO, E. C.; OLIVEIRA, G. C.; DIAS JUNIOR, M. S.; CURI, N.; COSTA, K. A. P.; CARDUCCI, C. E. Preconsolidation pressure, soil water retention characteristics, and texture of Latosols in the Brazilian Cerrado. Soil Research, Melbourne, v. 51, n. 3, p. 193202, 2013.

SILVA, E. A.; OLIVEIRA, G. C.; CARDUCCI, C. E.; SILVA, B. M.; OLIVEIRA, L. M.; COSTA, J. C. Doses crescentes de gesso agrícola, estabilidade de agregados e carbono orgânico em Latossolo do Cerrado sob cafeicultura. Revista Ciências Agrárias, Belém, v. 56, n. 1, p. 25-32, 2013.
SILVA, M. A. S.; MAFRA, A. L.; ALBUQUERQUE, J. A.; ROSA, J. D.; BAYER, C.; MIELNICZUK, J. Propriedades físicas e teor de carbono orgânico de um Argissolo Vermelho sob distintos sistemas de uso e manejo. Revista Brasileira de Ciências do Solo, Viçosa, MG, v. 30, n. 2, p. 329-337, 2006.

SILVA, M. L. N.; CURI, N.; BLACANEAUX, P. Sistemas de manejo e qualidade de Latossolo Roxo. Pesquisa Agropecuária Brasileira, Brasília, v. 35, n. 12, p. 2485-2492, 2000.

SLEUTEL, S.; BOUCKAERT, L.; BUCHAN, D.; VAN LOO, D.; CORNELIS, W. M.; SANGA, H. G. Manipulation of the soil pore and microbial community structure in soil mesocosm incubation studies. Soil Biology \& Biochemistry, Elmsford, v. 45, n. 2, p. 40-48, 2012.

SOARES, J. L. N.; ESPÍNDOLA C. R.; CASTRO, S. S. Alteração física e morfológica em solos cultivados sob sistema tradicional de manejo. Revista Brasileira de Ciências do Solo, Viçosa, MG, v. 29, n. 6, p. 1005-1014, 2005.

TIRLONI, C.; VITORINO, A. C. T.; BERGAMIN, A. C.; SOUZA, L. C. F. Physical properties and particlesize fractions of soil organic matter in crop-livestock integration. Revista Brasileira de Ciências do Solo, Viçosa, MG, v. 36, n. 4, p. 1299-1309, 2012.

VIANA, J. H. M.; FERNANDES FILHO, E. I.; SCHAEFER, C. E. G. R. Efeitos de ciclos de umedecimento e secagem na reorganização da estrutura microgranular de Latossolos. Revista Brasileira de Ciências do Solo, Viçosa, MG, v. 28, n. 1, p. 11-19, 2004.

VITORINO, A. C. T.; FERREIRA, M. M.; CURI, N.; LIMA, J. M.; SILVA, M. L. N.; MOTTA, P. E. F. Mineralogia, química e estabilidade de agregados do tamanho de silte de solos da Região Sudeste do Brasil. Pesquisa Agropecuária Brasileira, Brasília, v. 38, n. 1, p. 133-141, 2003. 